\title{
Characterization and Valorization of Two Algerian Bentonites in the Waterproofing Systems
}

\author{
Messaouda Debieche*, Farid Kaoua \\ Environment, Geotechnic and Hydraulic Laboratory (LEGHYD), Faculty of Civil Engineering, University of \\ Sciences and Technologies Houari Boumediene, Algiers, Algeria \\ Email: ${ }^{*}$ mdebieche@yahoo.fr
}

Received 14 February 2014; revised 16 March 2014; accepted 27 March 2014

Copyright (C) 2014 by authors and Scientific Research Publishing Inc.

This work is licensed under the Creative Commons Attribution International License (CC BY). http://creativecommons.org/licenses/by/4.0/

\section{Abstract}

The interest in environment has recently considerably grown, and its protection is now included in the continuous action of the governments and the industries. In Algeria, the different types of waste are currently produced in almost 3.000 illegal dumps, occupying approximately 150.000 hectares. To overcome this problem, waterproofing sites prove the most appropriate solution. It is a geotechnical method to guard against the action of water by narrowing the flow of water through a surface in a given time. The site's waterproofing technique, in the landfills sites, is nowadays a very necessary condition to protect the environment, which requires the use of appropriate materials. This work deals within the valorization of local materials (sand and bentonite), in the waterproofing technique of the technical landfills site "TLS". To this end, two types of bentonites from the west of Algeria are used. In order to achieve an optimal mixture, ensuring good performance in terms of hydraulic conductivity, durability and shear strength, mixtures based of sand at different concentrations of bentonite, at compact state are prepared and studied. This study showed that a low permeability of mixture (sand/bentonite) can be achieved with introducing $8 \%$ of a calcium bentonite, against $6 \%$ of a sodium bentonite. The latter presents a great adsorption capacity and a self healing ability, compared to calcium bentonite. This gives a good sustainability against climate variations of mixture based on sodium bentonite. This mixture has also confered a good mechanical behavior, expressed by the recorded, reduction of the friction angle $(\Phi)$ and the increase of the cohesion (C). Therefore it represents an optimal mixture for waterproofing systems, due to its economical and ecological advantages.

\section{Keywords}

Calcium Bentonite, Sodium Bentonite, Sand, Hydraulic Conductivity, Sustainability, Shear Strength

\footnotetext{
*Corresponding author.
} 


\section{Introduction}

The existence of stocks of industrial waste, and household garbage on the surface, pose major environmental problems. In Algeria, this problem begins to be felt, and becomes a concern of the environmental and geotechnical specialists, who care for the achievement of the sustainable developments [1].

The primary interest for environment protection increases the requirement of high quality and reliable sealing systems; the main characteristics sought are:

- A maximum dry density of the compacted mixtures sand/bentonite.

- A low hydraulic conductivity $\left(\mathrm{K} \leq 1 \times 10^{-9} \mathrm{~m} / \mathrm{s}\right)$ to minimize leakage using a small percentage of bentonite.

- A sufficient shear strength to maintain slope stability in TLS.

- The sustainability of the mixture should be checked vis-a-vis the climate changes in consecutive hydration properties over time (cycles of wetting-drying).

Nowadays, the use of the bentonitical geosynthetic, for the soil sealing is one of the most used worldwide.

Even though there are many worldwide research works, which were carried out on the hydraulic performance of bentonites, there are very few on the Algerian bentonite [2]. The Table 1 summarizes some results, found in the literature about similar worldwide researches.

In Algeria, the most important bentonite deposits are found in the west of Algeria (Figure 1). They have been exploited since the 1950s.

In this context, first, an experimental campaign was conducted in order to define, the concentration of bentonite necessary to achieve a low permeability $\left(\mathrm{K} \leq 1 \times 10^{-9} \mathrm{~m} / \mathrm{s}\right)$, the compaction characteristics and the possible variation of "K", allowing a sustainability study of the required mixture. Second, a study of the mechanical behavior is conducted, to evaluate the mechanical characteristics at short and long term of required mixture.

\section{Materials Used}

Two types of bentonite are used in this study:

- The bentonite of Mostaganem which is grayish.

- The bentonite of Maghnia (Roussel1) which is whitish.

Both bentonites are marketed by the National Company of Mineral Products Non Ferrous Bental (ENOF), to be used in foundry, ceramic industry or the oil and hydraulic drilling. The selection criteria are shown in Table 2.

The used sand comes from alluvial deposit of the north of Baghlia — the eastern of Algeria — usually used in the manufacture of concrete. A prior washing of the sand is performed to remove all impurities.

\subsection{Chemical Analysis}

The chemical analysis of the two used samples of bentonite, prepared in the form of pellets, was carried out by X-ray spectrometer, fluorescence spectra acquisition, and mathematical processing are performed by software Super Q. To do this, the Philips Analytical spectrometer is used, in order to adding value to local products, in soil sealing, chemical compositions of Algerian bentonites are compared to the world wide bentonites (Table 3).

This table indicates that the bentonite of Maghnia, has similar characteristics to the bentonite of Wyoming and the Greece one. However, the bentonite of Mostaganem contains low percentage of alumina and high in calcium.

Table 1. Literature results review.

\begin{tabular}{rccccc}
\hline & Type of bentonite & Studied content of bentonite & Optimal content of bentonite & $\mathrm{K}_{\text {Optimal }}(\mathrm{m} / \mathrm{s})$ & Référence \\
\hline SP sand & Calcium & $0 \%-20 \%$ & $15 \%$ & & $10^{-9}$ \\
SW sand & Sodium & $0 \%-10 \%$ & $5 \%$ & {$[3][4]$} \\
SM sand & & & & \\
SM sand & Sodium & $0 \%-6 \%$ & $4 \%$ & $10^{-11}$ & {$[3][5]$} \\
Silicate sand & Sodium & $5 \%-50 \%$ & $50 \%$ & $1.21 \times 10^{-12}$ & {$[3][6]$} \\
Dune sand & Calcium & $0 \%-15 \%$ & $15 \%$ & $<10^{-8}$ & {$[7]$} \\
\hline
\end{tabular}




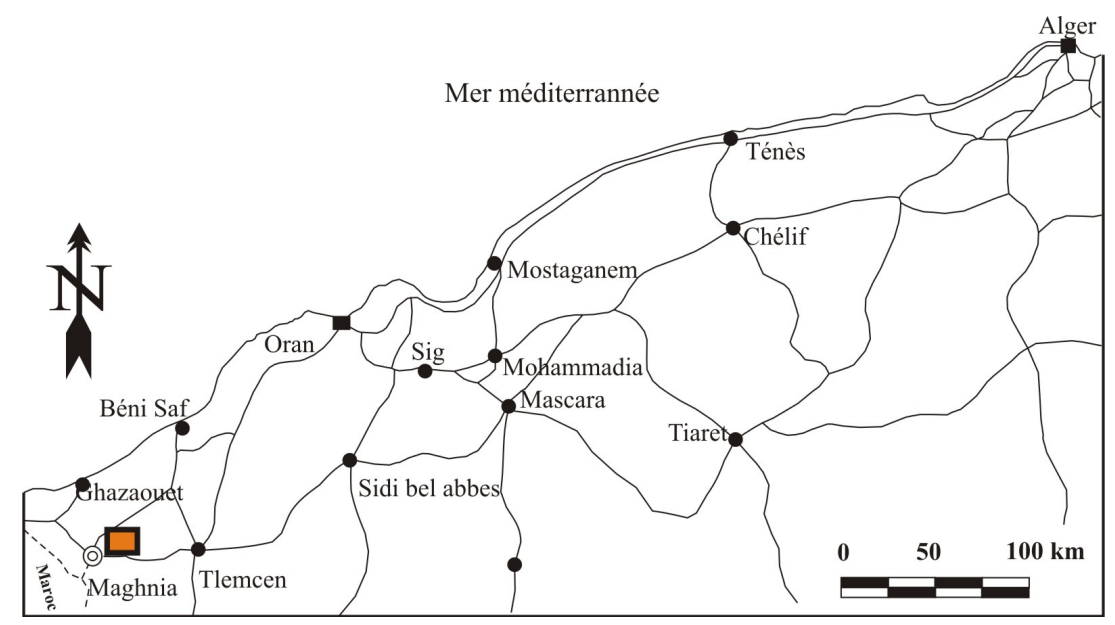

Figure 1. Location map of the bentonite deposit in Algeria.

Table 2. Criteria for the selection of compounds the bentonite [2].

\begin{tabular}{ccccccc}
\hline Category & $\mathrm{SiO}_{2}(\%)$ & $\mathrm{Al}_{2} \mathrm{O}_{3} \%$ & $\mathrm{MgO} \%$ & $\mathrm{Na}_{2} \mathrm{O} \%$ & $\mathrm{CaO} \%$ & viscosité \\
\hline Drilling mud & 50 to 65 & 15 to 25 & $2-3$ & $>2$ & - & - \\
Foundry & 50 to 65 & 15 to 25 & $2-3$ & - & $<1$ & - \\
Discoloring earth & 50 to 65 & 15 to 25 & $3-5$ & $>1$ & - & - \\
Pelletizing & 50 to 65 & 15 to 25 & $2-3$ & -1 & - \\
\hline
\end{tabular}

Table 3. Comparison of chemical compositions of the worldwide and Algerian bentonites.

\begin{tabular}{|c|c|c|c|c|c|c|c|}
\hline \multicolumn{6}{|c|}{ Some worlwide bentonites } & \multicolumn{2}{|c|}{ Algerian bentonites } \\
\hline * & $\begin{array}{l}\text { Kutch } \\
\text { Inde\% }\end{array}$ & $\begin{array}{c}\text { S \& B } \\
\text { Greece } \%\end{array}$ & $\begin{array}{l}\text { Wyoming } \\
\text { Federal \% }\end{array}$ & $\begin{array}{c}\text { Wyoming } \\
\text { Black hill \% }\end{array}$ & $\begin{array}{l}\text { South of } \\
\text { the USA \% }\end{array}$ & $\begin{array}{c}\text { Bentonite of } \\
\text { Mostaganem \% [3] }\end{array}$ & $\begin{array}{l}\text { Bentonite of } \\
\text { Maghnia \% }\end{array}$ \\
\hline $\mathrm{SiO}_{2}$ & 45.43 & 60.83 & 58.14 & 66.12 & 59 & 60.49 & 64.98 \\
\hline $\mathrm{Al}_{2} \mathrm{O}_{3}$ & 16.4 & 17.9 & 21.73 & 17.01 & 18.4 & 12.70 & 16.08 \\
\hline $\mathrm{Fe}_{2} \mathrm{O}_{3}$ & 14.05 & 4.34 & 2.46 & 2.46 & 5.1 & 2.70 & 2.93 \\
\hline $\mathrm{CaO}$ & 1.18 & 1.9 & 0.86 & 1.37 & 3.88 & 3.60 & 0.61 \\
\hline $\mathrm{MgO}$ & 2.43 & 2.83 & 2.42 & 1.51 & 2.86 & 2.29 & 3.51 \\
\hline $\mathrm{K}_{2} \mathrm{O}$ & 0.13 & 1.98 & 0.52 & 0.54 & 0.78 & 2.28 & 2.02 \\
\hline $\mathrm{Na}_{2} \mathrm{O}$ & 3.1 & 2.96 & 2.08 & 2.02 & 0.41 & 1.55 & 3.88 \\
\hline $\mathrm{TiO}_{2}$ & 1.86 & I & / & I & / & 0.30 & 0.20 \\
\hline Loss on ignition & 13.28 & 6.44 & 5.3 & 7.3 & 8.31 & 13.80 & 6.07 \\
\hline
\end{tabular}

The two bentonites are composed of a high percentage of $\mathrm{SiO}_{2}$ than $\mathrm{Al}_{2} \mathrm{O}_{3}$ (Table 3). In fact, the $\mathrm{SiO}_{2} / \mathrm{Al}_{2} \mathrm{O}_{3}$ ratio for the bentonite of Mostaganem and that of Maghnia, are respectively 4.76 and 4.04, these values indicate the presence of a Montmorillonite [8]. As the balance of the percentage of calcium, from the sodium in the bentonite from Mostaganem, confirms that the latter is calcium type, against by the balance of the calcium to sodium in the case of the bentonite of Maghnia, which indicates that we have a sodium one [9]. 


\subsection{Mineralogical Analysis}

\subsubsection{X-Ray Diffraction Analysis}

The methods of investigation and mineralogical characterization of clays, concern mainly the X-ray diffraction and microscopic analysis (SEM). The diffractometer used is brand Philips PW1710 type, the generator voltage $45 \mathrm{kV}$ and $35 \mathrm{~mA}$. The wavelength $(\lambda)$ is used attached to $1.54 \mathrm{~A}^{\circ}$, corresponding to the base tube in copper $(\mathrm{Cu})$.

The X-ray diffraction patterns of the both of used bentonites, shown in Figure 2(a) and Figure 2(b), show the presence of montmorillonite (translated by the peak corresponding to an interplanar spacing of $15.36 \mathrm{~A}^{\circ}$ in bentonite of Mostaganem. Furthermore the appearance of illite, quartz, calcite and traces of felspath (orthoclase and albite) is found (Figure 2(a)) [3]. While in the bentonite of Maghnia, the montmorillonite is predominant compared toimpurities such as quartz, orthoclase and some traces of calcite (Figure 2(b)).

\subsubsection{Scanning Electron Microscope Analysis (SEM)}

The analysis of the photographs taken using the SEM type JEOL JSM 6830.

On the Figures 3, the pictures show that the both bentonite are consisting of aggregates, which are formed by

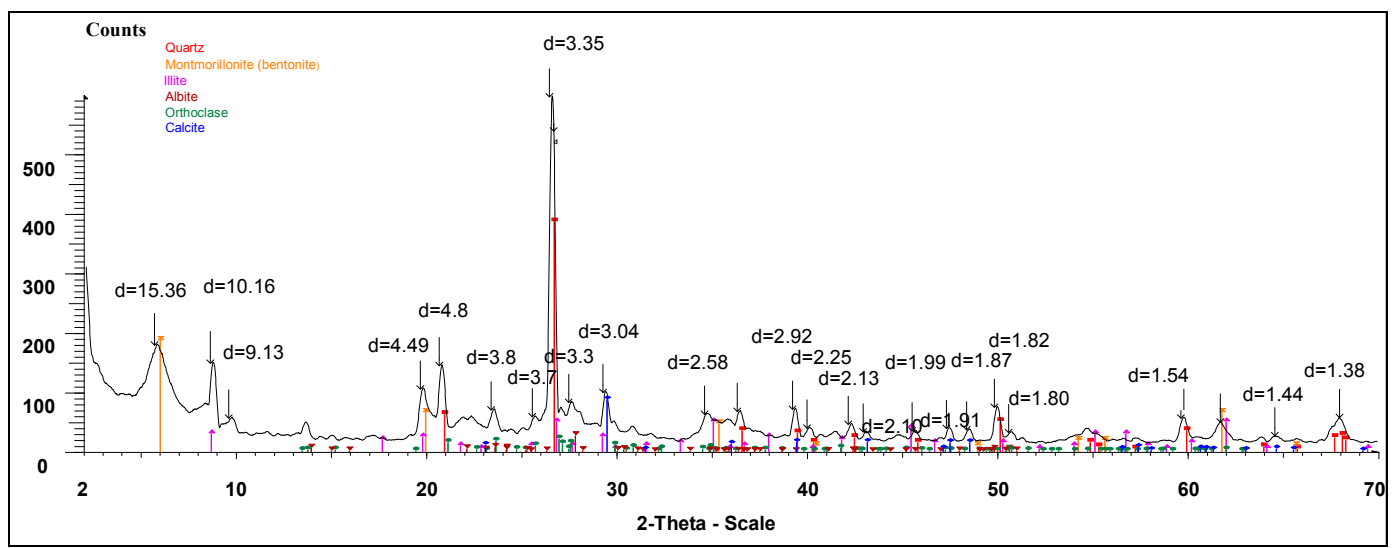

(a)

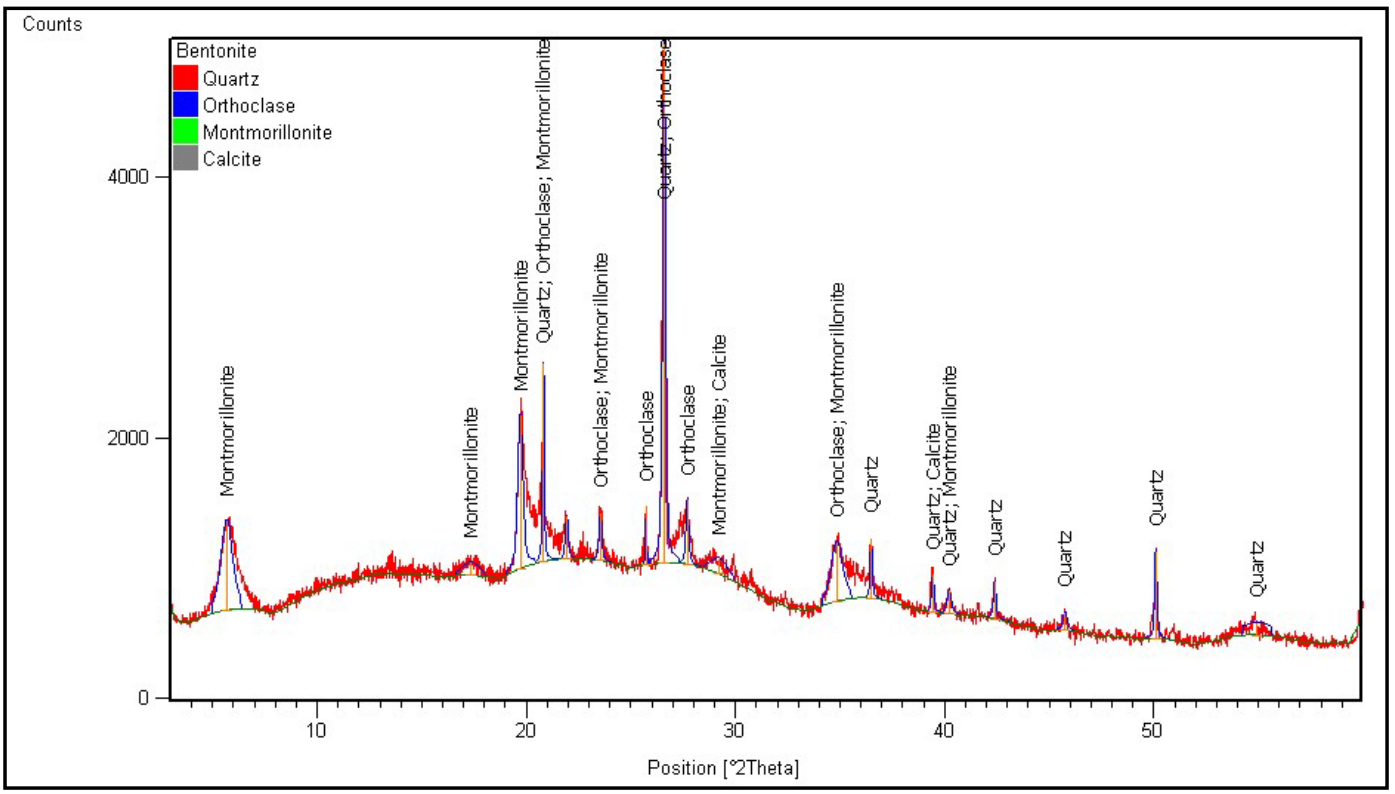

(b)

Figure 2. X-ray diffraction patterns of the two bentonites. (a) Bentonite of Mostaganem [3]; (b) Bentonite of Maghnia. 


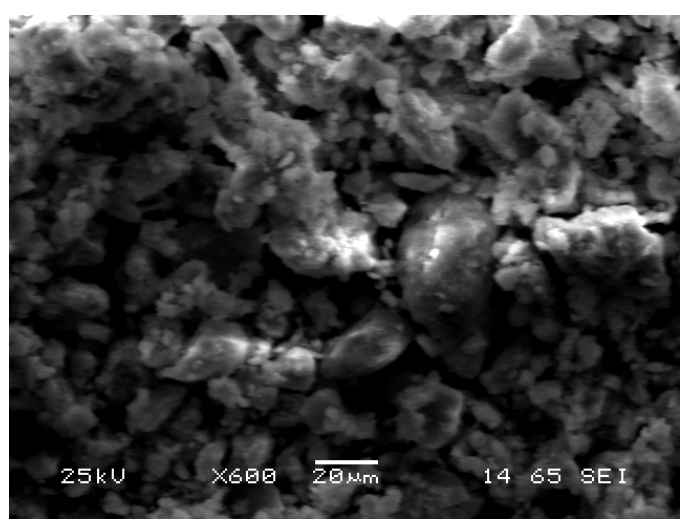

(a)

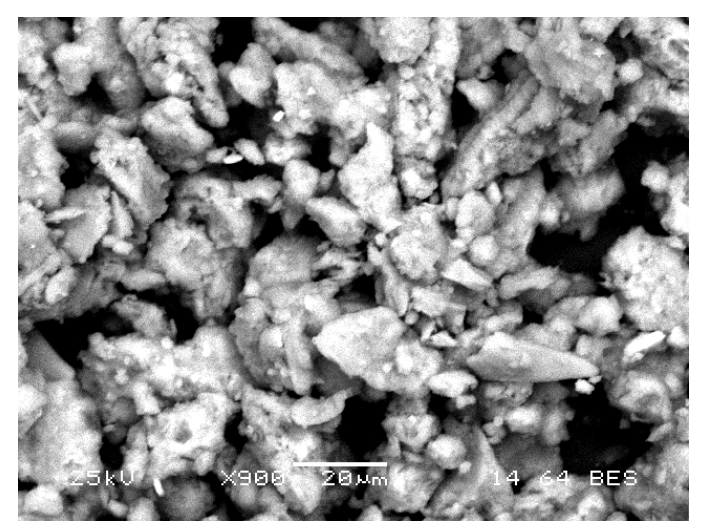

(b)

Figure 3. The photographies of the microstructures of the used materials, analyzed by SEM. (a) Bentonite of Mostaganem [3]; (b) Bentonite of Maghnia.

assembling the montmorillonite particles of various sizes. This assembly is accompanied by the appearance of microcavities of small sizes in Mostaganem bentonite compared to the Maghnia one.

\subsection{Physical Characteristics}

The physical characteristics are determined from standard laboratory tests, according to the standards, as shown in Table 4 and Table 5.

The characterization tests show that both bentonites are actives montmorillonite, having consequently a relatively large water adsorption potential. This gives them a possibility of their use in reducing the permeability. Bentonite of Maghnia is sodic (noted SB), while that of Mostaganem is calcic (noted CB). The used sand identification revealed that it is clean after the prewashing to remove all impurities, and bad graduated (noted $\mathrm{Sp}$ ).

The curves of sieving and sedimentometry, of the different used materials are plotted in the Figure 4, whose extracted informations are given bellow in Table 4 and Table 5.

\section{Hydraulic Performance}

This section deals with the determination of hydraulic performance, of the compacted mixtures, compound of the same sand and bentonites with different physico-chemical and mineralogical characteristics. The contents of the used bentonites are: $0 \%, 2 \%, 4 \%, 6 \%$ and $8 \%$.

The used sand was previously washed in order to eliminate all impurities (Table 5), and then dried in an oven at $105^{\circ} \mathrm{C}$ for 24 hours, while the bentonites have been dried at a temperature of $50^{\circ} \mathrm{C}$ for 48 hours.

This study concerns artificial sealing technique, where a soil (sand)_permeable — is mixed with the bentonite. Both (sand/bentonite) compacted at a specified water content, should ensure the permeability fixed by the regulations, and the cyclical effect humidification-drying.

Before studying the hydraulic performance of a soil, it is imperative to assess the optimal water content, giving the maximum dry density of each mixture by Standard Proctor (NF P94-093), according to the granulometry of the mixture and the site's usage.

This test consists on compacting the mixture, of particles whose diameter is less than $5 \mathrm{~mm}$, a rammer of 2.49 $\mathrm{kg}$ mass, a drop height of $30.5 \mathrm{~cm}$ in three layers, about $40 \mathrm{~mm}$ thick, in a standard mold with a diameter of 102 $\mathrm{mm}$ and a height of $117 \mathrm{~mm}$, with a relatively low compaction energy, which corresponds to a moderate compaction, evaluated at approximately $0.59 \mathrm{~kJ} / \mathrm{dm}^{2}$ ( 25 strokes per layer $)$. The mixture is prepared in a mixer $-5 \mathrm{li}-$ ters container, made of a stainless steel, and a rotary mixer alloy, revolving at a speed of $139 \mathrm{rev} / \mathrm{min}$ - wherein is introduced the dry sand and the required quantity of bentonite, then water is added. The mixture is mixed thoroughly, to obtain a homogeneous mixture. The conservation of the considered mixtures is ensured in sealed bags at room temperature for at least 24 hours [4] [10]. This step is necessary to keep constant the mixture humidity. Being sensitive to water, the bentonite requires more time for its homogenization. This process is repeated for the different considered mixtures, with different content of bentonite. 
Table 4. Results of identification tests of two the studied bentonites.

\begin{tabular}{|c|c|c|}
\hline Identification & Bentonite of Mostaganem [3] & Bentonite of Maghnia \\
\hline Natural water content $(\%)^{(1)}$ & 9 & 8.5 \\
\hline Specific density of solid grains. $\mathrm{Gs}^{(2)}$ & 2.70 & 2.72 \\
\hline Percentage of particles $<$ à $80 \mu \mathrm{m}^{(3)}$ & 100 & 100 \\
\hline Percentage of particles $\mathrm{C} 2<\mathrm{a} 2 \mu \mathrm{m}^{(3)}$ & 46.5 & 42.5 \\
\hline Liquidity limit. Wl (\%) $)^{(4)}$ & 187 & 240 \\
\hline Plasticity limit Wp (\%) ${ }^{(4)}$ & 45 & 43 \\
\hline Plasticity index Ip (\%) $)^{(4)}$ & 142 & 197 \\
\hline Consistency index Ic (\%) $)^{(4)}$ & 1.25 & 1.18 \\
\hline Withdrawal limit $\operatorname{Lr}(\%)^{(5)}$ & 13 & 10.24 \\
\hline Withdrawal index $\operatorname{Ir}(\%)^{(5)}$ & 174 & 229.76 \\
\hline Activity $(\%) \mathrm{Ac}^{(6)}$ & 3.89 & 6.06 \\
\hline Free swelling $(\mathrm{ml})^{(7)}$ & 23 & 35 \\
\hline Value of methylene blue test ${ }^{(8)}$ & 8.25 & 18.75 \\
\hline specific area $\left(\mathrm{m}^{2} / \mathrm{g}\right)^{(9)}$ & 168 & 394 \\
\hline $\mathrm{pH}^{(10)}$ & 8.6 & 10.3 \\
\hline
\end{tabular}

${ }^{(1)}$ Determined according to the standard NF P 94-050 procedure. ${ }^{(2)}$ Determined according to the standard NF P 94-054 procedure. ${ }^{(3)}$ Determined as described in standard NF P 94-056 and NF P 94-057. ${ }^{(4)}$ Determined according to the standard NF P 94-051 procedure. ${ }^{(5)}$ Determined according to the standard procedure ASTM D 427-61 and (XP P94-060-1) ${ }^{(6)}$ Determined according to the standard NF P 94-051 procedure Ac = Ip/C2 Skempton et al. (1953), Seed and al. 1962Ac $=\mathrm{Ip} /(\mathrm{C} 2-\mathrm{n})$, where $\left(\mathrm{n}=5\right.$ if the soil is intact $\mathrm{n}=10$ if the soil is edited). ${ }^{(7)}$ Determined according to the standard procedure ASTM D 5890 and planned in France NF P84-703. ${ }^{(8)}$ Measure with methylene blue test (test spot) after NF P 94-068. ${ }^{\left({ }^{(9)}\right.}$ Determine according to the standard procedure ASTM C 204-89. ${ }^{(10)}$ Determined a suspension of $20 \mathrm{~g}$ bentonite in $400 \mathrm{ml}$ of distilled water.

Table 5. Results of identification tests of the studied sand [3].

\begin{tabular}{cc}
\hline \multicolumn{1}{c}{ Designation } & Sand of Baghlia [3] \\
\hline Identification & 0.25 \\
\hline Percentage of particles $<\mathrm{à} 80 \mu \mathrm{m}^{(3)}$ & 2.65 \\
Specific density of solid grains $\mathrm{Gs}^{(2)}$ & 0.26 \\
Effective diameter $(\mathrm{mm}) \mathrm{D} 10^{(3)}$ & 3.46 \\
Uniformity coefficient Cu & 0.98 \\
Curvature coefficient $\mathrm{Cc}^{(3)}$ & 97 \\
Equivalent of sand $\mathrm{ES}(\%)^{(11)}$ & 0.012 \\
Value of methylene blue test & \\
\hline
\end{tabular}

${ }^{(2)}$ Determined according to the standard NF P 94-054 procedure. ${ }^{(3)}$ Determined as described in standard NF P 94-056 and NF P 94-057. ${ }^{(8)}$ Measure with methylene blue test (test spot) after NF P 94-068. ${ }^{(11)}$ Determined according to the standard procedure NF P 18-0598.

The Proctor curves are obtained, starting from a water content of about 4\% (Figure 5) and increase gradually. In general, the addition of water is stopped once the soil repulse is observed around the rammer compaction.

\section{Compaction Test Results}

The results are in the form of a curve on the Figure 5, which illustrate the dry density evolution depending to the water content. The optimum Proctor is graphically derived. 


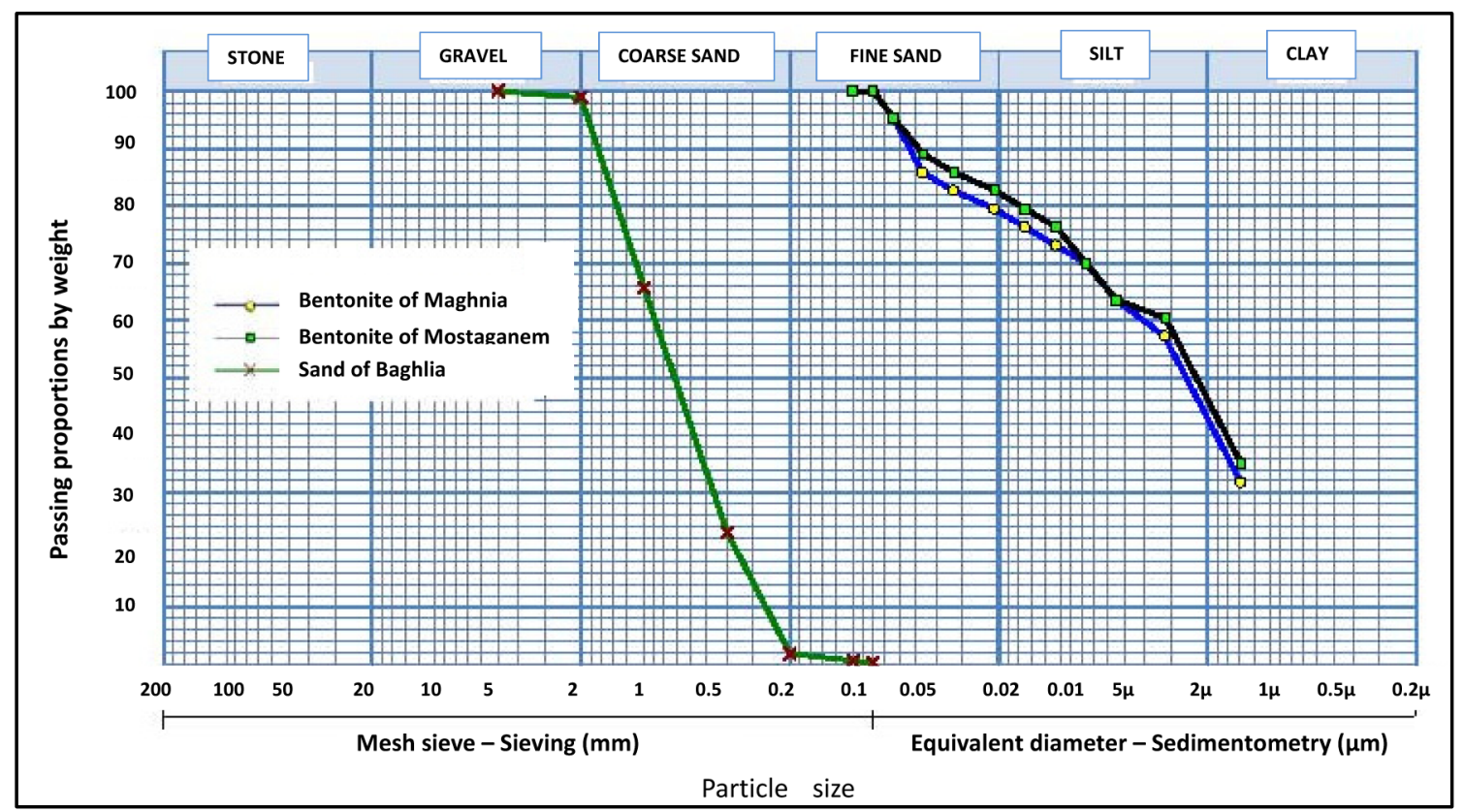

Figure 4. Grain-Size Distribution curves of three materials used in this study.

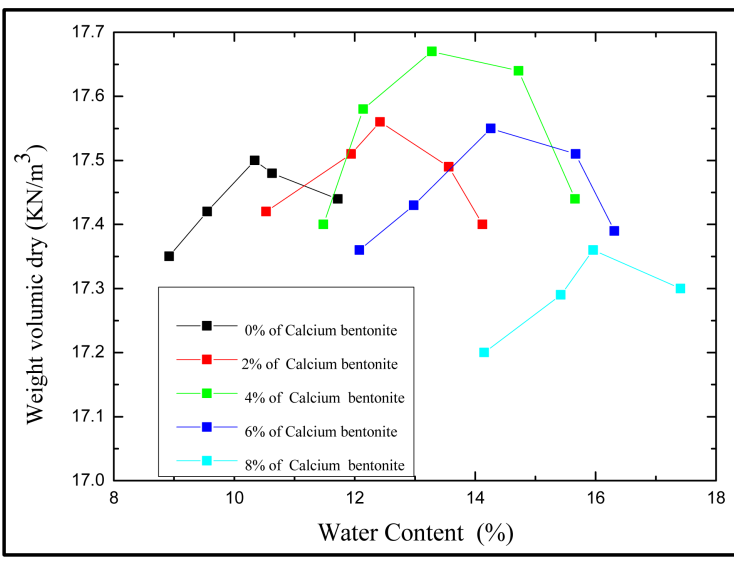

(a)

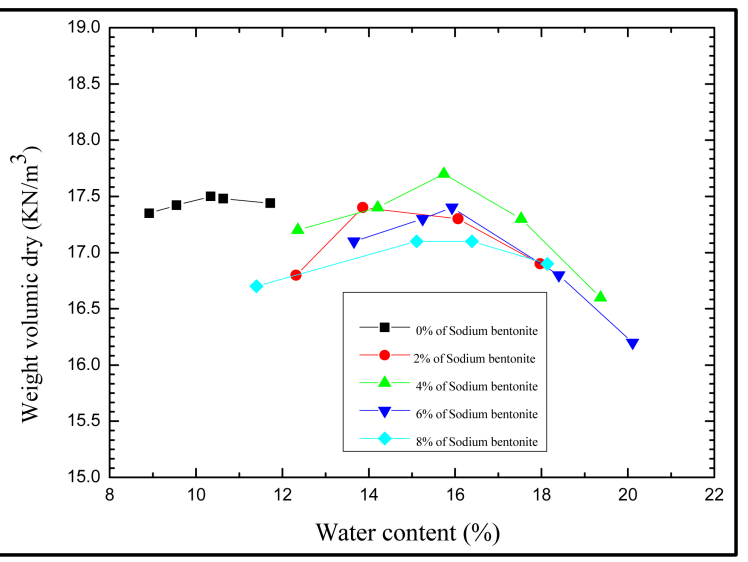

(b)

Figure 5. Weight volumic dry versus the water content, for the considered bentonite concentration. (a) Sand/CB; (b) $\mathrm{Sand} / \mathrm{SB}$.

The results allow us to follow up the change of the maximum of dry density, and the corresponding optimal water content, depending on the bentonite concentration. On the Figure 6, we notes that at low concentration of bentonite, their particles are rather driven between the sand grains, creating contact areas of sand granulate-togranulate. Whereas, above the concentration of $4 \%$ of bentonite, whose particles coat the sand ones, which reflects the mixtures' dry density decrease [10]-[13].

The two curves on Figure 7 show that the optimum water content is directly proportional to the concentration of bentonite. Furthermore, the optimal water contents of the mixtures of SB, are higher than those of mixtures of CB. This is explained by the high specific area, the plasticity index -to high-, the high rate of swelling of the SB of Maghnia (Table 3), and therefore a greater adsorption capacity than that of the CB of Mostaganem.

\subsection{Permeability Tests}

In general, determination of the coefficients of permeability to water, in the soil and-more generally, in the porous media - is based on the measurement of a flow rate, percolating through the microscopic porous struc- 


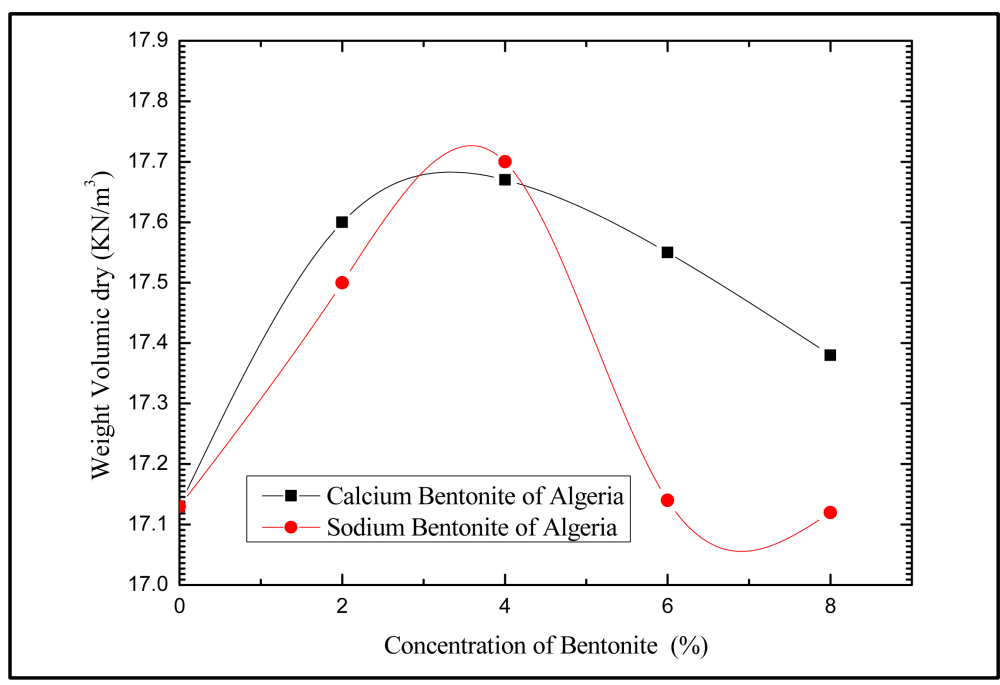

Figure 6. Evolution of dry volumic weight versus bentonite concentration.

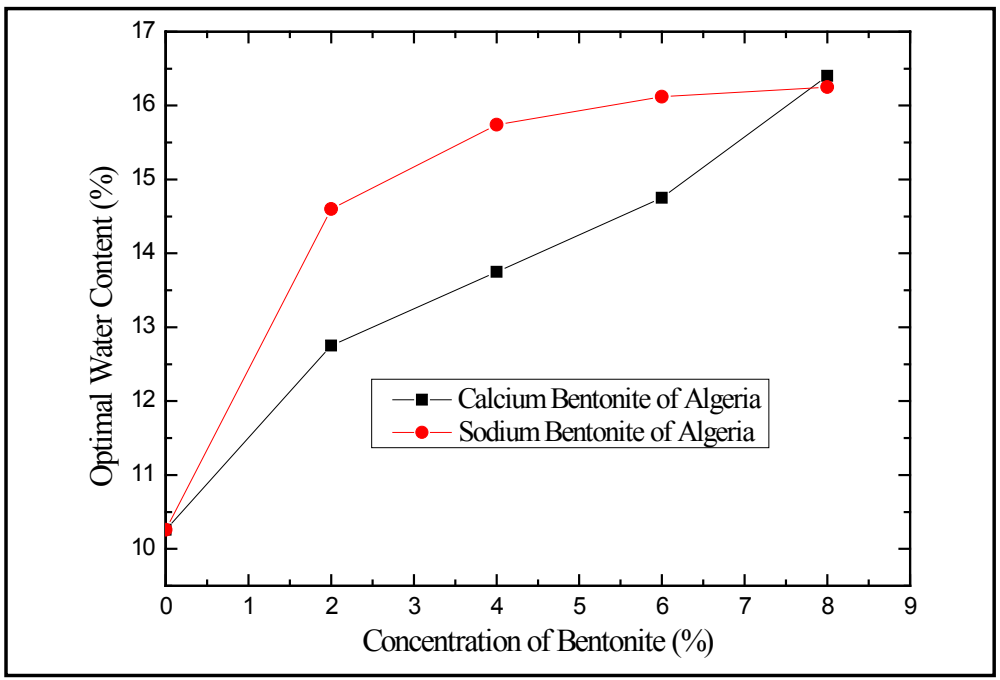

Figure 7. Optimal water content versus bentonite concentration.

ture, under the action of a positive or negative hydraulic load gradient. Free water and a capillary transfer governed by a mechanism, well reproduced by Darcy's law [14].

Given that we are interested to the sealing of compacted mixtures, all samples made for permeability tests, will be compacted on the wet side, thus the permeability tests are carried out at water contents equal to: $\omega=\omega_{\text {opt }}$ $+2 \%$ [15]. The direct measurement of soil permeability according to (NF P94-512-11), is based on two so-called "constant load" for soils with high permeability or "variable load" for soils with low permeability. In this study, the two procedures are performed, since the mixture consists on two types of soil, namely sand and a family of clays (montmorillonite). Once the optimum is obtained, from of the Proctor curve, the dry volumic weight and the corresponding content of water to be added are deduced. Another compaction test is carried out, this time, in the mold of Proctor permeameter, with a water content of the optimum $+2 \%$. The trials are conducted under the following conditions:

- The maintain of a low hydraulic gradient (noted $i)$, during the saturation phase $(i=1)$.

- The validity of Darcy's law;

- The measurement of permeability after saturation, especially after allowing the bentonite to swell completely;

- The temperature room is regulated at $20^{\circ} \mathrm{C}$, otherwise a corrections should to be made, according to the for- 
mula (3).

The device consists of a permeameter, for conducting the tests at constant and variable load simultaneously is presented on the Figure 8.

It includes:

- Four permeability cylindrical cell of $102 \mathrm{~mm}$ diameter and $117 \mathrm{~mm}$ height.

- A panel of four glass tubes of $17 \mathrm{~mm}$ in diameter, which is connected to the four-cell permeability, for the variable load test.

- A water tank for holding the specimen in the open air cell.

- A tank used to fill the four tubes for precise level $\left(h_{1}\right)$.

- Four metal rulers glued to the panel adjacent to the tubes, used to note the different water levels $\left(h_{2}\right)$.

\subsubsection{Constant Load Test}

For a constant load test, the permeability is given by:

$$
K=(Q / A i)
$$

where:

$K$ : the permeability $(\mathrm{cm} / \mathrm{s})$.

$Q$ : The volume of the water having passed through the sample, during the duration " $\mathrm{t}$ ".

$A$ : The sample area $\left(\mathrm{cm}^{2}\right)$, crossed by water.

$i$ : The hydraulic gradient $(\Delta H / L)$, with " $\Delta H$ " held constant, and " $L$ " the mold height.

\subsubsection{Variable Load Test}

For the variable load test, the permeability is given by:

$$
K(\mathrm{~cm} / \mathrm{s})=2.3 \frac{a \cdot L}{A \cdot T} \times \log \frac{h_{1}}{h_{2}}
$$

where:

$K$ : The permeability $(\mathrm{cm} / \mathrm{s})$;

$a$ : The piezometric tube area $\left(\mathrm{cm}^{2}\right)$;

$A$ : The sample area $\left(\mathrm{cm}^{2}\right)$;

$L$ : The mold length $(\mathrm{cm})$;

$T$ : The time to go from $h_{1}$ to $h_{2}(\mathrm{~s})$;

$h_{1}, h_{2}$ : The successive levels water in the tube during a " $\mathrm{T}$ " time.

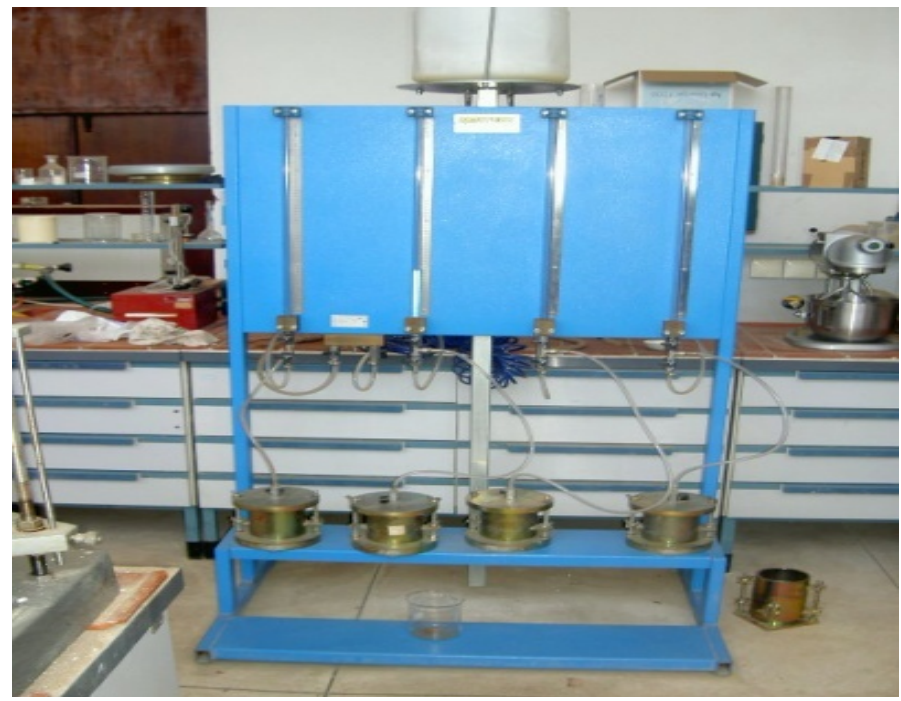

Figure 8. Photography of the device of the permeability test with a permeameter of compaction. 
The permeability coefficient depends on the fluid viscosity: when the viscosity increases, the flow decreases, and vice versa. It is therefore appropriate to bring back the calculated values of permeability $\mathrm{K}$, at a reference temperature, when the measurements are performed at various temperatures [16].

Conventionally, the coefficient of permeability " $\mathrm{K}$ " is given, for a temperature of $20^{\circ} \mathrm{C}$, where the water flows through the material, and the dynamic viscosity of water is of 1.00 MPa (AFNOR X30-441.2003).

$$
K_{20^{\circ} \mathrm{C}}=K_{T^{\circ} \mathrm{C}} \frac{\eta_{T^{\circ} \mathrm{C}}}{\eta_{20^{\circ} \mathrm{C}}}
$$

where:

$k_{20^{\circ} \mathrm{C}}$ : The permeability coefficient at $20^{\circ} \mathrm{C}$;

$k_{\mathrm{T}^{\circ} \mathrm{C}}$ : The permeability coefficient at the temperature $\mathrm{T}\left({ }^{\circ} \mathrm{C}\right)$;

$\eta_{20^{\circ} \mathrm{C}}$ : The dynamic viscosity at $20^{\circ} \mathrm{C}$;

$\eta_{\mathrm{T}^{\circ} \mathrm{C}}$ : The dynamic viscosity at the temperature $\mathrm{T}\left({ }^{\circ} \mathrm{C}\right)$.

An empirical relationship established by Helmholtz (1988), expressing the viscosity as a function of the temperature is:

$$
\eta=\frac{1.78}{1+0.0337 T+0.00022 T^{2}}
$$

\subsection{Hydraulic Conductivity}

To highlight the concentration of bentonite- $0 \%, 2 \%, 4 \%, 6 \%$ and $8 \%-$ effect on the water permeability, tests are carried out on mixtures of compacted sand-bentonite. For each percentage, two samples are tested, where the corresponding date, time, temperature and $\mathrm{pH}$ are noticed. The average duration of an experiment is valued at twenty days.

The Figure 9 shows the evolution of permeability according to the concentration of bentonite. Indeed, the addition of bentonite decreases permeability, which reached an optimal value at a specific percentage of bentonite, and varies a little after. The results found from a series of tests, show that for the same sand, permeability is involved by the percentage of bentonite, in other words, the permeability is inversely proportional to the concentration of bentonite. Thus the bentonite has the ability to reduce the permeability. Otherwise, for the studied mixtures, the lowest permeability is obtained for a concentration of $8 \%$ of bentonite Mostaganem (CB) and $6 \%$ of that of Maghnia (SB).

For a starting permeability of $3.93 \times 10^{-5} \mathrm{~m} / \mathrm{s}$, of the compacted sand at the optimum $+2 \%$, the addition of $8 \%$ of (CB) reduces the permeability of the mixture to $5.69 \times 10^{-11} \mathrm{~m} / \mathrm{s}$, while a permeability of $1.21 \times 10^{-11} \mathrm{~m} / \mathrm{s}$, is achieved with only $6 \%$ of (SB). This result is in agreement with the literature [5] [6].

\section{Cyclic Wetting-Drying Tests}

In order to check the sustainability vis-a-vis the climate constraints (due to climate change), and according to the method described above, both kinds of the given mixtures having the lower permeabilities, namely the mixture made with $6 \%$ of SB and the one of $8 \%$ of $\mathrm{CB}$ - through the time (during the lifetime of the landfills) - are now exposed to four cycles of humidifying-drying, by the measurement of permeability, before and after steaming. The drying is established by the oven process at $50^{\circ} \mathrm{C}$, (arbitrarily chosen, by the luck of standards, and based on seasonal variations in our country), to get constant weight.

The Figure 10 illustrates, that the CB loses its adsorption capacity, and therefore its permeability increases during humidification-drying cycles, this is explained by the calcium nature of this one [17]. Inter alia, the partial exchange of sodium ions by calcium ions, present in solution of the liquid hydration, leads to degradation of the swelling properties and waterproofing [18]. The degradation of hydration properties, resulting from the application of climatic stress over time (wetting-drying cycles), is much more pronounced for CB. In fact, the drying of the CB leads to a quasi-irreversible aggregation of the particles' face to face. This mixture loses the much of its swellability, which leads to the signifive increase of the permeability. Cracks appear in the drying and disappear during the hydration phase, the CB mixture loses its swelling capacity, and hence the self healing ability decreases. While the SB does not lose its adsorption capacity under cyclic effect, and hence its permeability keeps values in accordance with the Algerian regulations. In fact, the samples of SB mixing exposed to repeated 


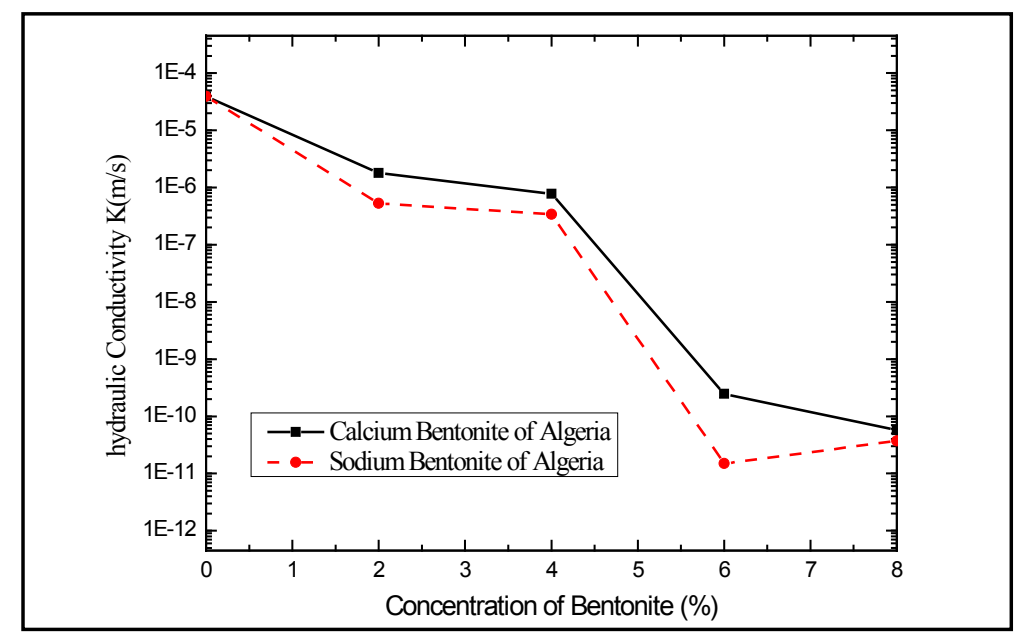

Figure 9. Hydraulic conductivity versus the bentonite content.

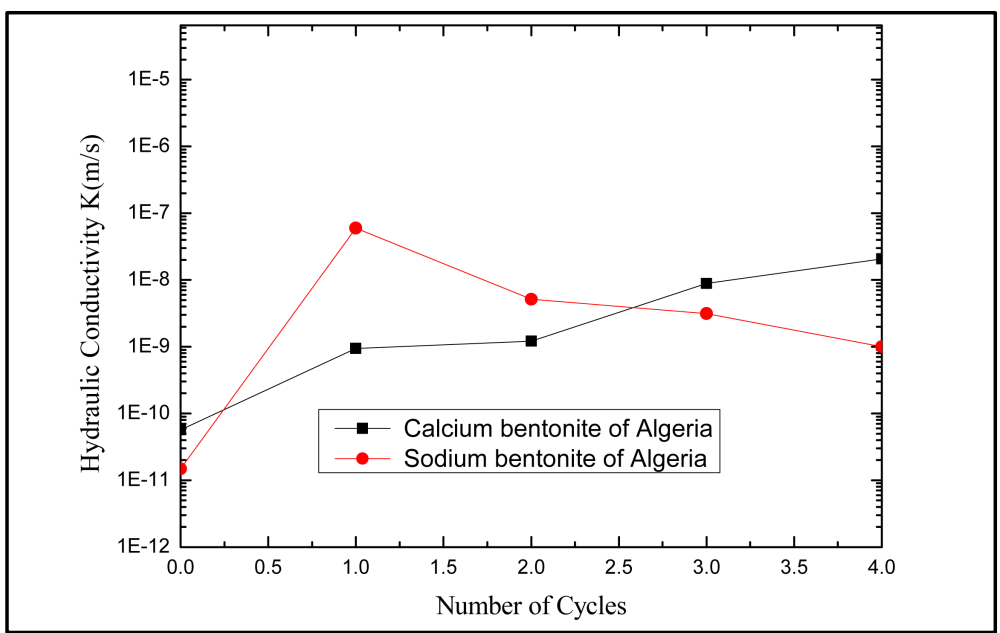

Figure 10. The effect of cycles of climatic variation on sand-bentonite mixtures.

wetting-drying cycles, have undergone an increasing of permeability, after the first cycle, after that, the permeability decreases (Figure 10). This is due to several reasons including:

- If the mixture is hydrated and then dried, shrinkage cracks may occur, which affects the permeability of the $1^{\text {st }}$ cycle. These cracks appear during the dried phase and disappear during the re-hydration one. The SB mixing does not lose completely its swelling capacity, this was confirmed from the second cycle, and therefore it has a self-healing ability [19].

- Given that the SB is used during the drying-humidification cycle, it does not lose its adsorption capacity over time, and thus its permeability is tested according to the Algerian regulation for different landfill classes.

Considering the sustainable behavior of the compacted SB, only this type of mixture will be used to study the mechanical behavior.

\section{Mechanical Characteristics}

Given that the waste storage centers are composed of sealing barriers, to limit the migration of water inside the waste, and the fluid contaminants to groundwater. These barriers are located on sloping, in deep, or hedges. They are therefore subjected to shearing forces, which may affect the stability of the system, due to the low strength at the interfaces of different materials in contact. In order to avoid breakage, or significant deformations, when the sites are subjected to the maximum loads, it is important to know the ultimate strength of the soil. 
The aim of this part is to determinate the mechanical characteristics ( $\mathrm{C}$ which is the cohesion and $\phi$ the internal friction angle), of the studied above mixtures (compacted S/SB).

\section{Procedure}

The box shear test (or direct shear test), is performed according to the standard (NF P 94-071-1). The Direct shear machine used in our study has a Casagrande box of $(60 \times 60) \mathrm{mm}^{2}$. The $\mathrm{S} / \mathrm{SB}$ mixture is compacted and clipped using a cutting kit, then placed in the box shear through a manual press. The assembly is introduced into the shearing unit. Two types of tests are carried out:

The unconsolided-undrained test, (UU) "short term", where speed of the machine is set to $1 \mathrm{~mm} / \mathrm{min}$, so as to impose a constant horizontal displacement. The machine is started immediately after application of the normal load, and then the readings are taken (Figure 11).

Regarding the Consolidated-Drained (CD) "long-term" test, where the sample is flooded, then consolidated under the vertical stress, in the shear apparatus until stabilization "which can last more than 24 hours". The machine speed is set at $0.002 \mathrm{~mm} / \mathrm{min}$, to impose a very slow constant horizontal displacement, between the two half-boxes, before starting the machine (Figure 12).

For each shear box test type, three normal stresses are used 100, 200 and $300 \mathrm{KPa}$. The $\mathrm{C}$ and $\varphi$ values are determined graphically, according the following Mohr-Coulomb equation.

$$
\tau=c+\sigma \tan \varphi
$$

where:

$C$ and $\varphi$ are respectively the cohesion and internal friction angle.

$$
\begin{gathered}
\sigma_{N}=\frac{N}{A} \\
\tau=\frac{T}{A}
\end{gathered}
$$

$\sigma_{N}$ and $\tau$ : Respectively, the normal and the shear stress.

$N$ and $T$ : Respectively, the normal and the tangential force.

The Mohr-Coulomb envelope curves, obtained from different direct box shear tests, of the S/SB mixture, which are compacted at water content of $\left(w_{\mathrm{op}}+2 \%\right)$, are shown on the Figure 13 and Figure 14.

The test results of the direct box shear on the S/SB mixtures, show an increase of the cohesion from 16.3 to 70 $\mathrm{KPa}$ for the UU test, and 16.3 to $62 \mathrm{KPa}$ for the CD test, where the percentages of bentonite is in the ranging from 0 to $8 \%$. In this case, the clay fraction contributes to increase the cohesion, and acts as a binder in filling the voids between the sand particles (Figure 15). The internal friction angle of the mixture S/SB changes from $39^{\circ}$ to $24^{\circ}$, for the UU test and from $39^{\circ}$ to $33^{\circ}$ for the CD test. This decrease becomes more pronounce from $4 \%$ of bentonite (Figure 16). This is explained by the increase of the clay fraction, and the decreasing of the sand fraction (friction generating), first. On the other hand, the water occupies a large part of the mixture's empty.

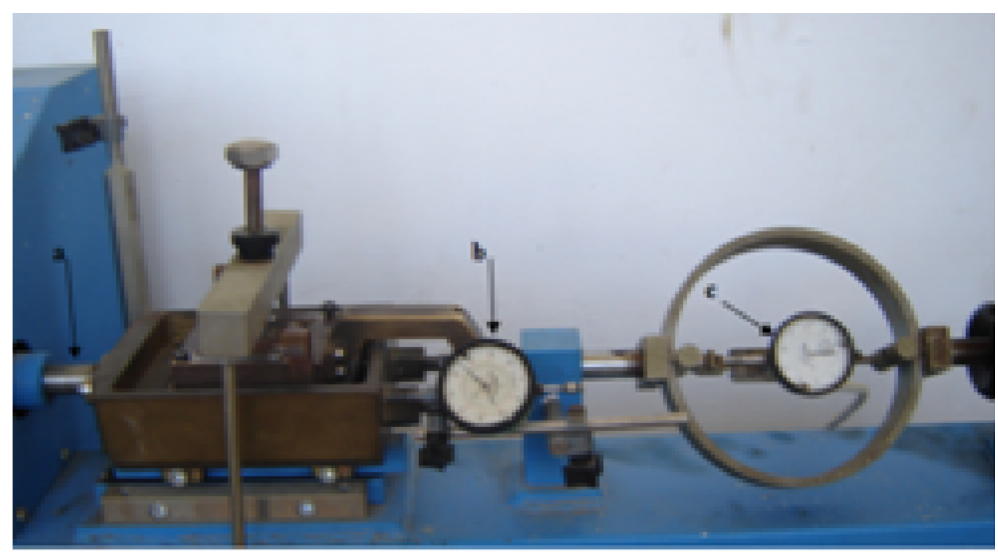

Figure 11. The UU shear test device. 


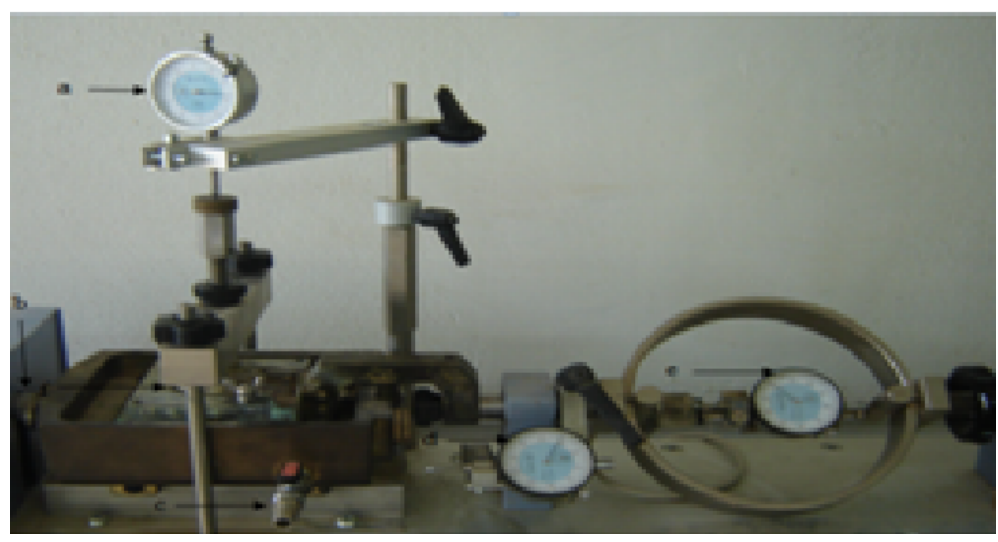

Figure 12. The CD shear test device.

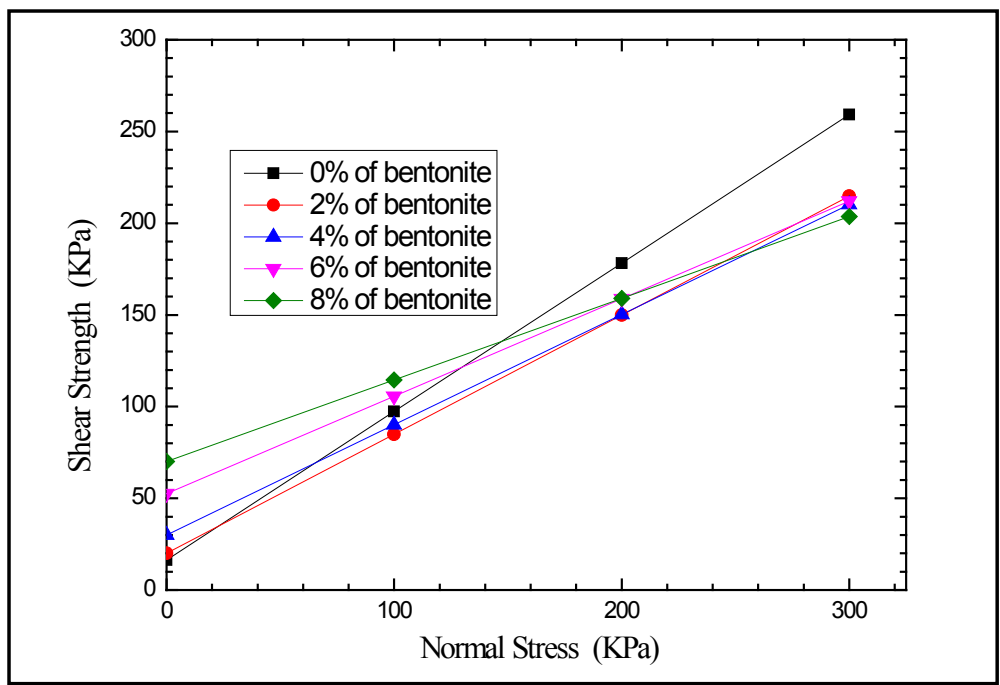

Figure 13. Mohr-Coulomb straight intrinsic for different percentages of bentonite (UU).

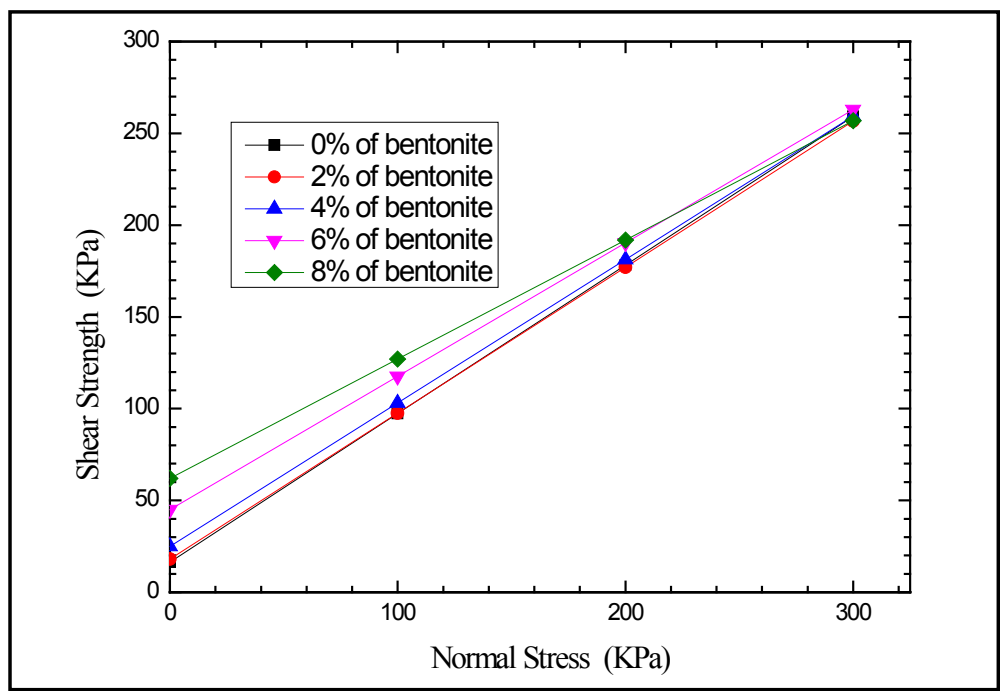

Figure 14. Mohr-Coulomb straight intrinsic for different percentages of bentonite (CD). 


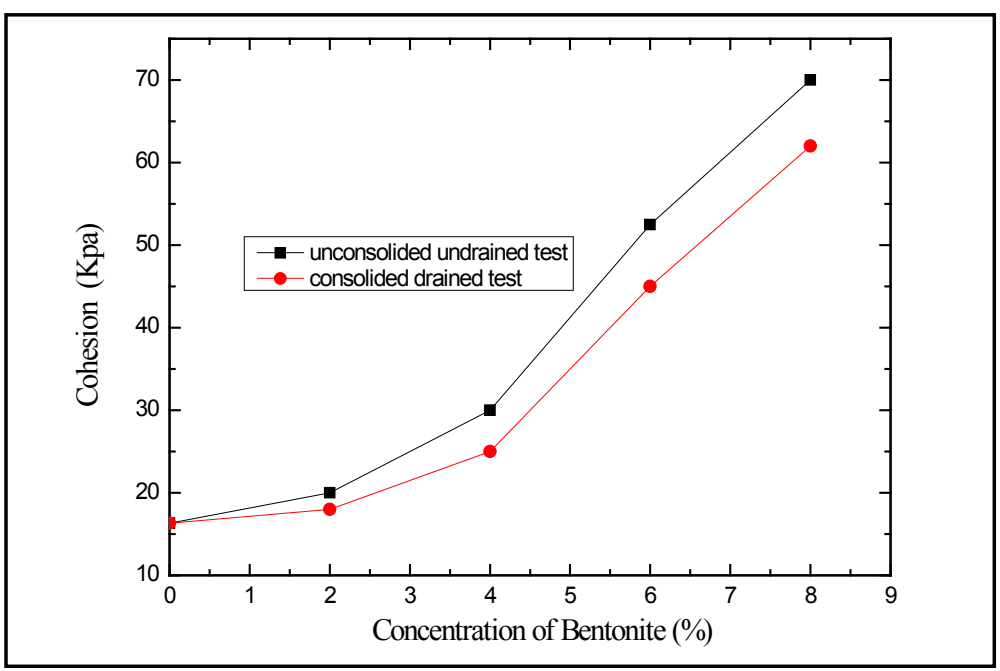

Figure 15. Evolution of cohesion versus the percentage of bentonite.

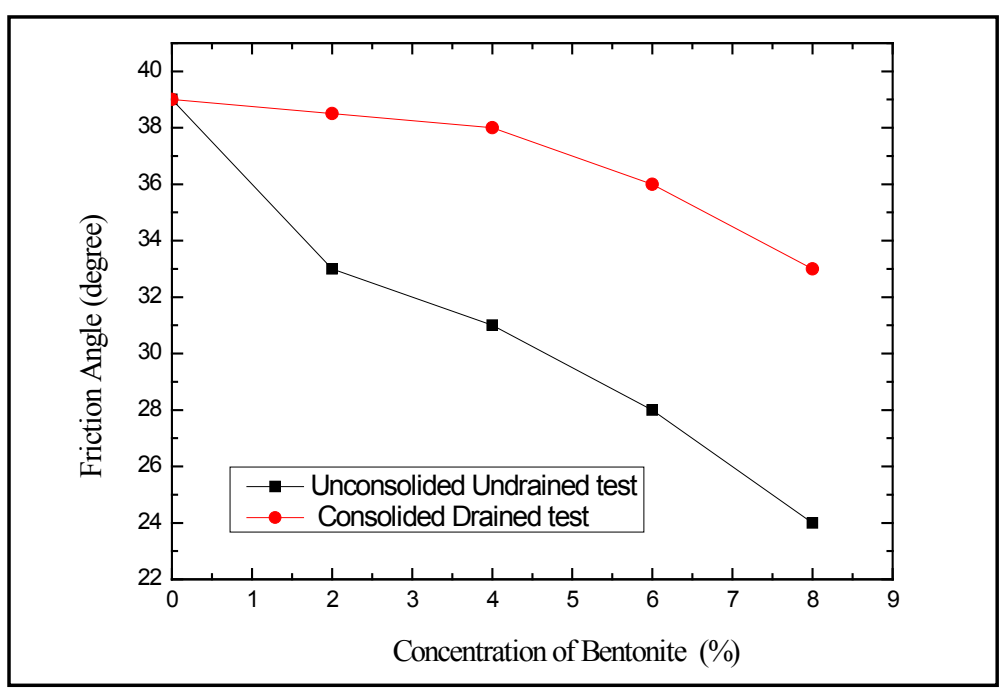

Figure 16. Evolution of the internal friction angle $(\varphi)$ versus the percentage of bentonite.

Being incompressible, it absorbs a significant amount of compaction energy, which prevents the particles of the mixture to adopt a more dense structure [20]. This reduces the inter-granular mixture's friction, which in their turn lose contact with each other, when the compaction is carried out on the wet side [21].

The hydraulic conductivity changes in the friction angle, depending to the bentonite content are shown on the Figure 17. For small percentage of bentonite $(<4 \%)$, the mechanical behavior is controlled by the sand fraction. Against by, beyond this value, the sand particles will not anymore be in contact, and the behavior is thus controlled by the bentonite content.

The addition of bentonite led to a low permeability of about $1 \times 10^{-11} \mathrm{~m} / \mathrm{s}$, but can create a problem in the mechanical stability, which leads us to take precautions, for the achievement of the sloping waterproof barriers. In agreement with the literature, the hydraulic conductivity and friction angle are conversely proportional to the increasing of bentonite content [7].

\section{Conclusion}

This work allowed us to experimentally study, the maximum dry density, hydraulic conductivity, durability and shear strength of different mixtures of S/B. The performed tests on S/B mixtures, allowed us to draw up the fol- 


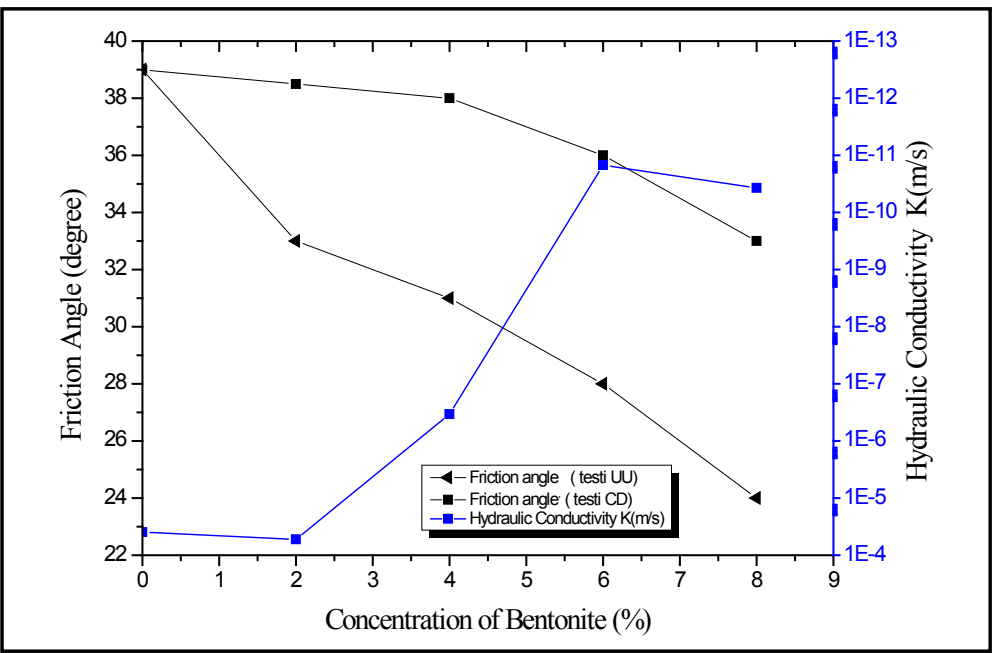

Figure 17. The hydraulic conductivity and friction angle according to the bentonite percentages.

lowing conclusions:

- The optimal water content of the mixtures depends on the increase of the bentonite concentration.

- A very low value of permeability (of the order of $10^{-11} \mathrm{~m} / \mathrm{s}$ ), is achieved by introducing of $8 \%$ of CB, against only $6 \%$ of SB. This is explained by a high specific area, an index fairly high plasticity, and a high rate of swelling SB from Maghnia, and therefore a greater adsorption capacity, than CB one from Mostaganem.

- During the "wetting-drying" cycles, an increasing in the permeability of the mixture based on CB is observed, due to the loss of the swelling capacity and the reduction of the self healing of the CB. Unlike the SB mixtures which exhibit good durability vis-a-vis the climatic variations due to the self healing of this one.

- The adding of the SB to the sand generates a reduction of the friction angle $(\phi)$ and an increase in the cohesion $(\mathrm{C})$.

- Due to the availability of materials in Algeria, its proper behavior towards mechanical, hydraulic and climatic constraints, the optimal mixture is the one compound of $6 \%$ of $\mathrm{SB}$, which bestows a dual economic and ecological advantage, for waterproofing systems in coverage or at the bottom of the waste disposal centers.

\section{References}

[1] Zebdji, M. (2000) Solid Waste Management in the Governorate of Greater Algiers. Proceedings of the International Seminar on Integrated Solid Waste Management. Algiers. Algeria. Mate. 2006: Programme National de Gestion des déchets ménagers.

[2] BENTAL-ENOF (2010) Etude technique et économique des gisements de M'Zila (Mostaganem) et Hammam Boughrara (Maghnia) Vol I Rapport Final, BUMIGENE.INC. Monréal (Québec) Canada H3B 1P5.

[3] Debieche, M. (2007) Imperméabilisation d'un matériau pulvérisant par ajout de bentonite. Thèse de magister de la Faculté de Génie Civil. Université des Sciences et de la Technologie Houari Boumediene, Alger, Algérie.

[4] Gleason, M.H., Daniel, D.E. and Eykholt, G.R. (1997) Calcium and Sodium Bentonite of Hydraulic Containment Application. Journal of Geotechnical and Geoenvironmental Engineering, 123, 438-445. http://dx.doi.org/10.1061/(ASCE)1090-0241(1997)123:5(438)

[5] Didier, G. and Cavalcante Rocha, J. (1998) Définition des conditions optimales de traitement en place d'un sol perméable en vue de son imperméabilisation, Rap. Subvention № 90012, Min. de l'environnement, Direction Générale de l'Administration et du Développement, Service de la Recherche et des Affaires Economiques, 215 p. http://dx.doi.org/10.1139/t95-100

[6] Komine, H. (2004) Simplified Evaluation on Hydraulic Conductivities of Sand-Bentonite Mixture Backfill. Department of Urban and Civil Engineering, Ibaraki University, 4-12-1 Nakanarusawa-cho, Hitachi, Ibaraki, 316-8511, Japan, Available online.

[7] Gueddouda. M.K., Lamara, M., Aboubaker, N. and Said, T. (2008) Hydraulic Conductivity and Shear Strength of Dune Sand-Bentonite Mixtures. EJGE, 13, 2008 -Bundle H. 1-15 
[8] Lin, L.C. and Benson, C.H. (2000) Effect of Wet-Dry Cycling on Swelling and Hydraulic Conductivity of GCLs. Journal of Geotechnical and Geoenvironmental Engineering, 123, 402-410.

[9] Grim, R. and Guven, N. (1978) Bentonite: Geology, Clay Mineralogy Properties and Users. Elsevier Science Publishing, New York.

[10] Daniel, D.E. (1994) State of the Art: Laboratory Hydraulic Conductivity Tests for Saturated Soils, Hydraulic Conductivity and Waste Containment Transport in Soil. ASTM STP1142, ASTM, 30-78.

[11] Holtz, R.D. and Kovac (1981) An Introduction to Geotechnical Engineering. Prentice Hall, New Jersey.

[12] Lambe, T.W. (1958) The Structure of Compacted Clay. Journal of the Soil Mechanical and Foundation Division ASCE, 84, 1-35.

[13] Ait saadi Lotfi. (2003) Méthodologie de contrôle de l'homogénéité et de la perméabilité des barrières argileuses. Institut National des Sciences Appliquées de Lyon.

[14] Moussai, B. (1993) Etude en laboratoire du compactage statique et de la perméabilité des sols fins argileux. Thèse de doctorat de l'institut National des Sciences Appliquées de Lyon.

[15] Robinet, J.C. and Rhattas, M. (1995) Détermination de la perméabilité non saturée des matériaux argileux à faible porosité. Canadian Geotechnical Journal, 32, 1035-1043.

[16] SETRA/LCPC (1992) Réalisation des remblais et des couches de forme-Fascicule I: Principes généraux. Guide technique du Ministère de l'équipement, du logement et des transports.

[17] Jaynes, D.B. (1990) Temperature Variations Effect on Field-Measured Infiltration. Soil Science Society of America Journal, 54, 305-312. http://dx.doi.org/10.2136/sssaj1990.03615995005400020002x

[18] Boardman, B.T. and Daniel, D.E. (1996) Hydraulic Conductivity of Desiccated Geosynthetic Clay Liners. Journal of Geotechnical Engineering, 122, 204-209. http://dx.doi.org/10.1061/(ASCE)0733-9410(1996)122:3(204)

[19] Tessier, D. (1984) Etude expérimentale de l'organisation des matériaux argileux. Hydratation, gonflement et structuration au cours de la dessiccation et de la ré-humectation. Thèse de doctorat, Université Paris VII, 361 p., INRA Versailles Ed

[20] Mitchell, J.K. (1976) Fundamentals of Soil Behaviour. J. Wiley \& Sons, Toronto.

[21] Delage, P. and Fry, J.I. (2000) Comportement des sols compactés: apport de la mécanique des sols non saturés. Revue Française de géotechnique, 17-29. 